\title{
Systematic Literature Research of the Current Implementation of Unmanned Aerial System (UAS) in the Construction Industry
}

\author{
Hamlet Reynoso Vanderhorst, Subashini Suresh, Renukappa Suresh
}

\begin{abstract}
The implementation of UAS is bringing easiness and time saving activities into the currently construction site task. In the construction industry, diverse and relevant benefits of the technology have been identified through the project life cycle, such as monitoring project progress report, faster and low-cost land measurements and $3 D$ modelling. Currently, the most valuable benefits of the UAS in the construction industry are related to automation the construction process, low cost, greater speed and safer real-time data collection compare with the traditional methods, and a reliable replacement over satellites and manned vehicles in terms of high-resolution images. However, there is a lack of exemplification and clarity of the actual implementation of the UAS in the construction industry in terms of adoption process and impacted usage. Therefore, a systematic literature review was carried out in order to explore the literature available of the topic related to implementation of unmanned aerial system in the construction industry, the most relevant tasks, cases, areas of usage and the reasons of applying it. The finding of this paper is providing exemplification models of current usage such as visualisation and disaster management, evolution map of the UAS according to the publication numbers and construction project stages when to use the UAS.
\end{abstract}

Keywords- Drone, Construction, Project life Cycle, Unmanned Aerial Systems, UAV Unmanned Aerial Vehicle.

\section{INTRODUCTION}

The Unmanned Aerial System (UAS), generally recognised as drones, have been utilised by militaries in nations such as Australia, United States of America, and United Kingdom in military activities. In the last decade, the implementation of UAS into commercial and civilian daily life applications has been increasing substantially improving jobs clarity and reducing risk involved in the tasks.

The implementation of UAS is bringing easiness and time saving into the currently jobs task. Researchers and practitioners across the world have been showing interest in implementing UAS in the fields of archaeology, forest and agricultural, environmental, autonomous surveillance, emergency and disaster management, traffic surveillance and management, photogrammetry for 3D modelling, architecture and construction [1] [2] [3] [4].

Hamlet Reynoso-Vanderhorst, Faculty of Science and Engineering, School of Architecture and the Built environment, University of Wolverhampton, Wolverhampton, United Kingdom.

(Email: h.d.reynosovanderhorst@wlv.ac.uk)

Dr Subashini Suresh, Faculty of Science and Engineering, School of Architecture and the Built Environment, University of Wolverhampton, Wolverhampton, United Kingdom.

(Email: S.Subashini@wlv.ac.uk)

Dr Suresh Renukappa, Faculty of Science and Engineering, School of Architecture and the Built Environment, University of Wolverhampton, Wolverhampton, United Kingdom.

(Email: Suresh.Renukappa@wlv.ac.uk)
Revised Manuscript Received on September 10, 2019.

The benefits of UAS are mainly implemented because of its low cost, fast speed, high manoeuvrability, safer data collection images [5], and a reliable replacement over satellites and manned vehicles in terms of high-resolution images [6]. Therefore, the implementation of UAS implies management and technical challenges. Some of the management challenges are concerning to legal, ethical, device selection and insurance issues. In the technical level can be listed the challenges of pre-flight planning, deployments, weather conditions, quality of the data, battery life time and platform integration. However, the benefits of the UAS implementation is reasonably enhancing the visualisation of the project, speed of real-time data collection, implementation of other technologies and the way of share information.

The construction industry has been benefitted from the implementation of UAS. The construction project life cycle generally is described by the inception or feasibility, strategy, construction and completion stages [7]. Each of the stages contains specific activities that could be utilised the UAS and its outcomes in order to improve the construction project process and the communication between the parties involved. The relevant tasks that UAS face are progress reports, land surveying, 3D modelling, monitoring construction and building inspections which have specific phases to be applied during the project [8]. The following tasks are the most relevant for utilising UAS in the construction industry:

- Progress Report. The UAS has integrated sensors capable to acquire visual data and georeferenced. The visual data can be analysed with and without processing system.

- Land Surveying. The UAS capture visual data undertaking photogrammetry technique and georeferenced. Then, the pixels of the data gathered are processed into a software (Pix4D, DroneDeploy or Agisoft) and obtain contour lines and surface models of the area. Furthermore, measurements of volume and area can be carried out. The accuracy is relative to $10 \%$ of error depending on the UAS utilised.

Monitoring the Construction site. The visual data gathered by the UAS allows the team and managers to identify the possible hazards on site. Moreover, the data also can be used for monitoring the transit of the area.

- Inspections of Infrastructures. The facilities managers and quality assurance of the project requires carry out inspects to the building erect or in process periodically. Visual data or processed as 3D models are used to navigate, 


\section{Systematic Literature Research of the Current Implementation of Unmanned Aerial System (UAS) in the Construction Industry}

register and collect as-built plant of high and large construction areas. 3D Modelling. After capturing the visual data undertaking the photogrammetry technique and georeferenced, the software can generate $3 \mathrm{D}$ models of the building or site with colour and texture. This outcome is converted to a point cloud format where is utilised by architects to create designs in the surface purposed.

The application of UAS is well known and understood by research and contractors. However, there is a lack of exemplification and clarity of the actual implementation of the UAS. The review presented in this paper is intending to summarize undertaking a systematic methodology approach concerning the actual implementation of UAS in the construction industry in terms of adoption process and impacted usage.

However, there is a lack of exemplification and clarity of the actual implementation of the UAS in the construction industry in terms of adoption process and impacted usage. Therefore, a systematic literature review was carried out in order to explore the literature available of the topic related to implementation of unmanned aerial system in the construction industry, the most relevant tasks, cases, areas of usage and the reasons of applying it. The UAS is utilised and benefit the construction industry directly. In addition, researchers and scholar obtain a higher understanding of the UAS implementation. The systematic review was done by VOS Viewer software based on text mining method. The systematic review brings the concept of autonomous robots in construction which encourage explore tasks that UAS with the appropriate sensor and cargo ability could address.

\section{A. Unmanned Aerial Systems (UAS)}

Since World War II, the concept of aerial photogrammetry has been seen in doves equipped with cameras and aerostatics globe with armaments. Suddenly, the word "Drone" has appeared commercially since 2013 when civilian and commercial companies designed and lunched the first drones ready to fly to fly DJI and Parrot. The International Civil Aviation Organisation (ICAO) is the responsible entity on charge of the international air navigation. The ICAO [9] in 2011 published the document Cir 328 called Unmanned Aircraft Systems (UAS) (Drone) in order to establish basic regulatory framework to safely and harmonise the integration of UAS in the airspace. Afterwards, the national's government aviation entities have promulged with regulations to manage appropriately the operations of UAS as the case of United Kingdom, United States and Australia. The UAS has different named according to it context, weight, and country which is mentioned. In the construction industry was found three major keywords which cover the main core of the publications in the last 10 years.

\section{B. Implementation of UAS in the Construction} Industry

The implementation of UAS is bringing the easiness and time-saving activities into the current jobs task [10]. Some frameworks propose the path to identify the task (Morgenthau et al., 2019) and the requirement that an operation would be required [11] The most valuable benefits of the UAS in the construction industry are related to automation the construction process, low cost, greater speed and safer real-time data collection compared with the traditional methods [12] and a reliable replacement over satellites and manned vehicles in terms of high-resolution images [13]. Technology usually is applied in order to decrease dependency on hand-operated labours, reduce issues of quality, increase productivity and control over asbuilt plans [13]. The challenges of applying them are mostly concerning lack of qualified professionals, ethical issues, device selection and regulatory barriers. The most relevant used for a progress report and land surveying [14] primary then other applications are discovered during the process. Sensors, simulations and educational aspects are involved when digitalisation is taking part in organisations. However, there is a lack of exemplification and clarity of the actual implementation of the UAS in the construction industry through the project life cycle.

\section{RESEARCH METHODOLOGY}

The research strategy of the literature review is a systematic review. The review method coves five steps: definition of the research question, location of the studies, selecting questions, analysis of the literature, synthesis and finally report the findings. The aim of this research strategy is to locate and assess the existing studies, analyse, summarise and report the research evidence providing an objective conclusion of the subject to investigate. In order to properly perform the literature exploration some questions such as:

- When is used the UAS during a project life cycle?

- What are the most relevant cases that the UAS are used?

- What are the areas of usage the UAS?

- Why are used UAS in construction Industry?

To address the questions presented, a data-based mined with bibliographic peer-reviewed papers were collected. The data-base was reached utilising modal keywords found during a five-phase step process: Keywords selection, Literature exploitation, Text mining, The network visualization, Words selection, and location of the network link map.

\section{Keywords Selection}

The keywords were explored utilising a web search engine which identified the most common labels of drones in a professional, research and policymaker environment. The label drones have different terminology according to the context, weight and country which is mentioned (Table I). 
Table - I. The Keywords of Drones Search

\begin{tabular}{|l|l|}
\hline Name & Abbreviation \\
\hline Drone & - \\
\hline Unmanned Aircraft & UA \\
\hline $\begin{array}{c}\text { Remotely Operated } \\
\text { Aircraft }\end{array}$ & ROA \\
\hline $\begin{array}{c}\text { Remotely Piloted } \\
\text { Vehicle }\end{array}$ & RPV \\
\hline $\begin{array}{c}\text { Unmanned Aerial } \\
\text { Vehicle }\end{array}$ & UAV \\
\hline $\begin{array}{c}\text { Unmanned Aerial } \\
\text { System }\end{array}$ & UAS \\
\hline
\end{tabular}

Furthermore, the keywords were merged along with "Construction" in the Scope database and download with the appropriate excel field to process with the text mining. The results provide the following filter process:

The first step was defining the area of study. The boundaries set of this search was according to the keywords were used in the following order: "Drone" "Construction", "UAS" "Construction", "UAV" "Construction", "RPAS" "Construction". The number of publications collected between February - March 2019 was exhausted, and it needs a second filter in order to assure the quality of the study.

The second filter allows to exclude the documents with more than 10 years, research areas outside of the investigation scope, documents without peer review and in order to assure quality journal and conference papers have been chosen (Table III).

Finally, were exported the citation and abstracts details to be visualised in VOS Viewer software. A total of 1,397 document have been found related to the topic. However, the aim of this research is to explore and summarize the literature available of the topic related to implementation of unmanned aerial system in the construction industry, the most relevant tasks, cases, areas of usage and the reasons of applying it.

Table- II. Keywords Publication Number

\begin{tabular}{|l|c|}
\hline Keywords & $\begin{array}{c}\text { Number of Publication } \\
\text { effective }\end{array}$ \\
\hline Drone Construction & 201 \\
\hline UAS Construction & 485 \\
\hline UAV Construction & 702 \\
\hline RPAS Construction & 9 \\
\hline Total & 1,397 \\
\hline
\end{tabular}

Table- III. Exclusion Criterial

\begin{tabular}{|l|l|}
\hline \multicolumn{2}{|c|}{ Exclusion Criterial } \\
\hline $\begin{array}{l}\text { Document } \\
\text { previously up } \\
\text { to: }\end{array}$ & 2009 \\
\hline Subjects of: & $\begin{array}{l}\text { Neuroscience, Pharmacology, } \\
\text { Immunology and Microbiology, } \\
\text { Psychology, Biochemistry, } \\
\text { Genetics and Molecular Biology, } \\
\text { Medicine, Agriculture, and Arts } \\
\text { \& Humanities. }\end{array}$ \\
\hline Document & Note, Article in Press and Short \\
\hline
\end{tabular}
(Table II) to be utilised for the search. Four keywords search

\begin{tabular}{|l|l|}
\hline Type: & Survey \\
\hline
\end{tabular}

Therefore, the term that researches have adopted to called drones is the Unmanned Aerial Vehicle or UAV as a result of the most literature published appeared with the keyword. To identify the keywords in the literature Scopus database, the VOS Viewer software was utilised in order to get a visualisation of the overall keyword's literature around the UAS topic in construction.

\section{A. Literature Exploitation}

The bibliographic peer-review database was composed of 1,397 manuscripts. Therefore, the database was introduced into a bibliographic text mining software with the aim to visualise the keywords and field of knowledge that the researchers have carried out studies.

The visual text analyses arrangement was carried out by the tool VOS viewer. The software VOS viewer is a tool capable of arranging and presenting bibliometrics link networks based on words occurrence, number of links, clusters and items. The links might become from journals, researchers, or individual publications, and arranging depend on the compilation of the references. The compilation can be a citation, bibliographic coupling, cocitation, or co-authorship relations. The VOS viewer offers the function of text mining which could be used to arrange and present visually in co-occurrence networks of relevant terms extracted from a body or abstract of scientific literature.

\section{B. Text Mining Method}

High-quality text information can be extracted from the manuscript applying the process of text mining. The process derives high-quality text through patterns and trends identification. Furthermore, the process involves statistical patterns of leaning analysis. The process of text mining frequently covers the structuring of the text data the process of structuring the input text, determination of patterns within the structured data, and finally assessment and meaning of the output.

In the text, mining is defined as the high-quality text of the data concerning some combination of relevance, novelty, and interest words. Often the text mining tasks encompass text categorization, clustering, concept extraction, taxonomies, sentiment analysis, document summarization, and entities relation modelling.

Some examples of the research applications of text mining text data are regarding predictive classification, populate a database and search extracted index information. A typical application is to scan a set of documents written in a natural language and either model the document set for predictive classification purposes or populate a database or search index with the information extracted. The text data mining techniques are links, association analysis, visualization, and predictive analytics.

In this systematic literature review were analysed the text data mining in the perspective of links, association analysis and visualisation with the aim to explore the literature concerning to carry out a 
search index of the topic related to the implementation of the unmanned aerial system in the construction industry. In Figure 1 is shown the text mining links words map. There are 3 clusters which can be interpreted in the followingperspective:

1) Cluster Blue - The words links and association present keywords that are usually mentioned by managers in a construction industry. The managerial perspective typically affiliated with the words associate with results oriented.

2) Cluster Red - The meaning of the words links, and association shows keywords from the operational level of management in the construction industry. The operational level shows keywords in a technical perspective.

3) Cluster Green - The keywords links and associations are connected to research areas that the construction industry is directed. The words are arranged with keywords that promote the research and analysis of the impact implementing UAS. For example, the word "topic" is linked with analysis, impact and evaluation words which is meaning a prominent area of research.

\section{The Network Visualisation}

The VOS Viewer software is presenting the words that have a high level of occurrence on the data based compiled. The words distance gap shows the strength of the links between literature words association. The distance and colours between the words are related to the occurrence relationship between them. The words of each cluster have been found associated between them in the same topic area. The closest relationship between them and they were mentioned collectively addressing a specific research area. The software is able to present the locations where there is a relevant amount of studies in the database.

The software imported three clusters which were defined by their words association and proximity appeared in the literature. The clusters colour red and blue are closer than the green one as a consequence of the research interest. The UAS technology is been developed under an industry basis rather than research. Furthermore, in each cluster is identified keywords that are interested in this review. The software has imported three clusters which were defined by their words association and proximity appeared in the literature

\section{Words Selection}

The aim of this systematic literature review is to summarize in a literature review concerning the actual implementation of UAS in the construction industry through the project life cycle. For this reason, the following keywords were extracted from the word network in order to find keywords that describe the implementation process of UAS in the construction industry. Some of the work found are mentioned in Table IV. The green cluster provides an understanding of the words to be studied. The keyword found are: "implementation", "performance" and "integration". The keyword implementation can be described as the relationship between managerial and research area. The implementation performs operations, researches, studies, analysis and simulation in order to explore the components, benefits and impact of UAS in the construction projects (Figure 2). Furthermore, there is another word that could be associated with "implementation" and its synonyms are the word "integration". This word presents a higher level of understanding and relationship links of the actual "implementation". In Figure 3 can be seen the words links that the word "integration" comes with it. In addition, in figure 4 is shown the word "performance" links. 
International Journal of Innovative Technology and Exploring Engineering (IJITEE)

ISSN: 2278-3075, Volume-8, Issue-11S, September 2019

Table IV. Words appeared in the Text mining map

\begin{tabular}{|c|c|c|c|c|c|c|}
\hline & Blue Cluster & & Red Cluster & & Green Cluster & \\
\hline No. & $\begin{array}{l}\text { Managerial } \\
\text { Perspective }\end{array}$ & Occurrence & $\begin{array}{l}\text { Technical } \\
\text { Perspective }\end{array}$ & Occurrence & $\begin{array}{l}\text { Research } \\
\text { Perspective }\end{array}$ & Occurrence \\
\hline 1 & Projects & 205 & UAV & 780 & Study & 435 \\
\hline 2 & Sensors & 168 & Image & 388 & Analysis & 335 \\
\hline 3 & Inspection & 153 & Drone & 254 & Research & 268 \\
\hline 4 & Tasks & 127 & Drone & 254 & Performance & 219 \\
\hline 5 & Requirements & 109 & Information & 185 & Operation & 188 \\
\hline 6 & Components & 91 & Monitoring & 177 & Aircraft & 180 \\
\hline 7 & Challenges & 80 & Work & 177 & Simulation & 135 \\
\hline 8 & Testing & 74 & Work & 177 & Simulation & 135 \\
\hline 9 & Details & 69 & Accuracy & 173 & Tool & 112 \\
\hline 10 & Hardware & 58 & Camera & 173 & Concept & 103 \\
\hline 11 & Maintenance & 52 & Accuracy & 173 & Efficiency & 101 \\
\hline 12 & Students & 50 & Point & 164 & Controller & 97 \\
\hline 13 & Variety & 45 & Order & 147 & Implementation & 93 \\
\hline 14 & Users & 45 & Photogrammetry & 126 & Effect & 93 \\
\hline 15 & Real Time & 35 & Robot & 125 & Evaluation & 87 \\
\hline 16 & & & Measurement & 119 & Issue & 80 \\
\hline 17 & & & Feature & 105 & Optimization & 78 \\
\hline 18 & & & Feature & 105 & Characteristic & 78 \\
\hline 19 & & & $\begin{array}{l}\text { Construction } \\
\text { Site }\end{array}$ & 104 & Investigation & 72 \\
\hline 20 & & & Map & 101 & Integration & 67 \\
\hline 21 & & & Site & 99 & Risk & 67 \\
\hline 23 & & & Software & 97 & Benefit & 47 \\
\hline 24 & & & Surface & 87 & Topic & 47 \\
\hline 25 & & & Position & 76 & & \\
\hline 26 & & & Object & 74 & & \\
\hline 27 & & & GPS & 56 & & \\
\hline 28 & & & Motion & 56 & & \\
\hline 29 & & & Interest & 43 & & \\
\hline 30 & & & Possibility & 38 & & \\
\hline 31 & & & $\begin{array}{l}\text { Experimental } \\
\text { Result }\end{array}$ & 36 & & \\
\hline
\end{tabular}

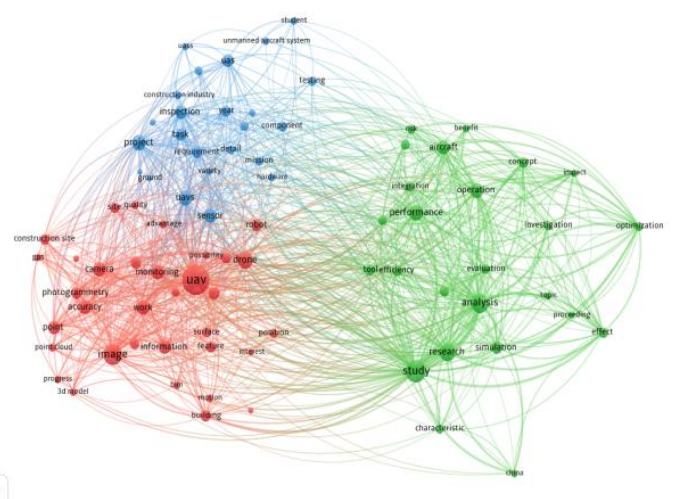

Fig 1: Text Mining Links and association map
Fig 2: Text mining links and association map of the keyword "implementation". 


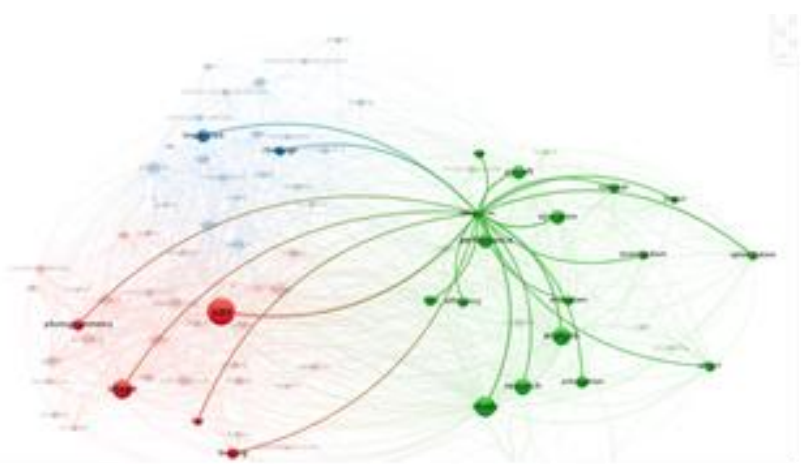

Fig 3: Text mining links and association map of the keyword "integration".

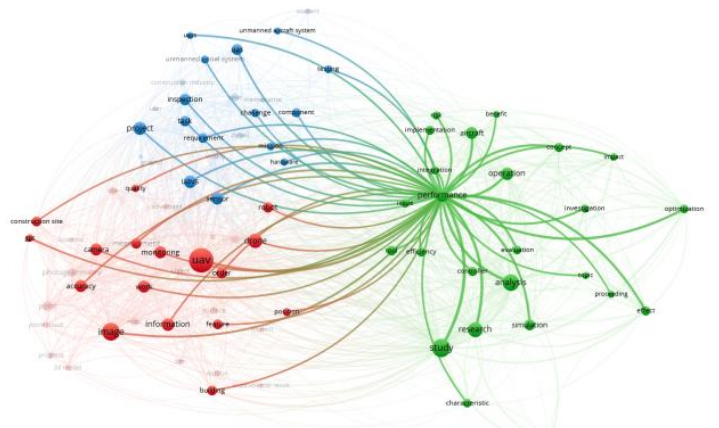

Fig 4: Text mining links and association map of the keyword "performance".

\section{E. Location of the network link map}

The research field of UAS has been developed across the world. However, there are countries which present significant development and literature on the topic. Figure 5 shows the locations that have been developed literature about UAS technology. The countries where the UAS has been prominently found literature is the United States of America (188), China (131) and Germany (52). For this reason, these countries might have addressed certain challenges and benefits of a successful implementation of UAS. Furthermore, from the keyword's selection, the perspective the text mining country outcome is The United States of America (48), China (25) and Germany (18) (Figure 6). The words implementation is following the same pattern of country research as well as the text mining general database. Therefore, a generalisation can be inferred because of this pattern and further investigation might be needed about these countries context and their UAS technology development in the construction industry.

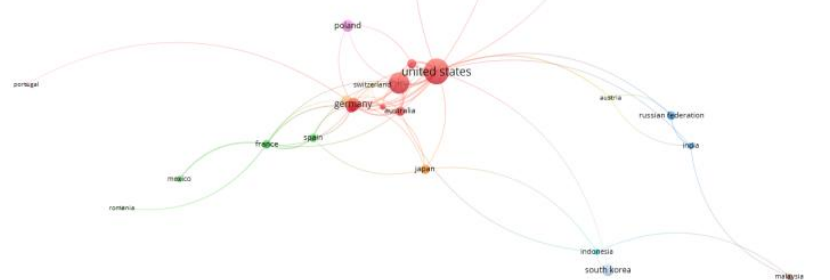

Fig 5: Text mining Map of countries

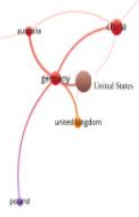

Fig 6: Text Mining Map of Countries in the words selected

The sample countries chosen based on the three words "implementation", "integration" and "performance" are providing information about publications and knowledge generation related to the UAS current application. Australia, the United Kingdom and the United State have experience using UAS for military reasons. However, the map is inferring that the United States, China, Germany, United Kingdom and Australia have been further testing on a scientific basis the UAS integration. The United States might be implementing the UAS successfully because of its entrepreneurial growth in terms of UAS solutions around the industry and the peaceful uses of UAS currently [15] [16]. In contrast with Germany which has been used by the government in order to make safer bridge inspections [17]. Furthermore, the United Kingdom has established a proper qualification in order to achieve the standards of professionalism in the sector [18]. In the other hand, China has been manufacturing the UAS into the market dominating the technology opportunity currently [20]. In addition, others as China have been encouraging the development of UAS and company as DJI has changed the UAS experience since 2006. Furthermore, Australia has been used for the agricultural and surveying purpose as a result of their large areas to be mapped, fertilized and optimized. Nevertheless, these countries are progressing along with their UAS market improving policies according to their country context, testing new technology such as UAS for cargo and agriculture, incorporating in their government affairs such as traffic supervision and bridge inspections [21][19]. However this field needs further research in order to address a higher understanding of these country UAS integration into their airspace

\section{LITERATURE CLASSIFICATION}

The implementation of UAS in the construction industry can be defined by the literature finding of the words "implementation", "performance" and "integration". These words are linked to the word's inspection, project component, research, concept impact, simulation and optimisation, challenge, photogrammetry, image, BIM, risk, testing, requirements, monitoring accuracy, camera quality, analysis and characteristic. These arrangements of words give an idea of where the UAS applications can be found in a management perspective. For this reason, the following systematic literature review has been generated based on 53 journals and 130 conference papers which provide high- 
quality data. In table $\mathrm{V}$ is shown the top 5 journals and conferences found in the systematic literature review with their its own cite score obtained by Scopus database

Table- V. Journals Score

\begin{tabular}{|l|l|l|}
\hline $\begin{array}{l}\text { No } \\
\cdot\end{array}$ & Journals & $\begin{array}{l}\text { CiteScor } \\
\text { e }\end{array}$ \\
\hline 1 & Automation in Construction & 5.36 \\
\hline 2 & Journal of Field Robotics & 4.42 \\
\hline 3 & $\begin{array}{l}\text { International Journal of Civil } \\
\text { Engineering and Technology }\end{array}$ & $\begin{array}{l}\text { Measurement: Journal of the } \\
\text { International Measurement } \\
\text { Confederation }\end{array}$ \\
\hline 5 & Machine Vision and Applications & 2.62 \\
\hline
\end{tabular}

Table- VI. Conference Score

\begin{tabular}{|l|l|l|}
\hline $\begin{array}{l}\text { No } \\
.\end{array}$ & Conferences & $\begin{array}{l}\text { CiteScor } \\
\text { e }\end{array}$ \\
\hline 1 & $\begin{array}{l}\text { Lecture Notes in Computer Science } \\
\text { (including subseries Lecture Notes in } \\
\text { Artificial Intelligence and Lecture Notes } \\
\text { in Bioinformatics) }\end{array}$ & 0.90 \\
\hline 2 & Procedia Engineering & 0.89 \\
\hline 3 & IFAC-PapersOnLine Conference & 0.68 \\
\hline 4 & $\begin{array}{l}\text { ACM International Proceeding Series } \\
\text { Prience }\end{array}$ & 0.49 \\
\hline 5 & $\begin{array}{l}\text { IOP Conference Series: Materials Sciencering } \\
\text { and Engineering }\end{array}$ \\
\hline
\end{tabular}

\section{RESULT AND DISCUSSION}

\section{A. Review of Literature}

In the following systematic literature have been found 53 journals and 130 conference papers that were assessed deeply in terms of the value delivered to the implementation of Unmanned Aerial System. The journals were providing information related to $36 \%$ Actual cases of Implementing UAS in the construction industry, $31 \%$ Design and Sensors implemented in the UAS, $24 \%$ Simulations of UAS, $2 \%$ Educational aspect of UAS and other journals that required the platform of UAS to produce new knowledge $8 \%$. In the other hand, the conference paper was providing knowledge concerning 35\% Actual cases of Implementation, 29\% Design \& sensors, $28 \%$ Simulations of UAS, $2 \%$ Educational aspect of UAS, and $6 \%$ platform of UAS to produce new knowledge as presented in table VII.

Table- VII. The distribution of the journals and conference papers.

\begin{tabular}{|c|c|c|c|c|}
\hline $\begin{array}{c}\text { Classificati } \\
\text { on }\end{array}$ & $\begin{array}{c}\text { Jour } \\
\text { nal }\end{array}$ & $\begin{array}{c}\text { Confere } \\
\text { nce }\end{array}$ & $\begin{array}{c}\text { Tot } \\
\text { als }\end{array}$ & $\%$ \\
\hline $\begin{array}{l}\text { Actual } \\
\text { Implementatio } \\
\text { n of UAS }\end{array}$ & 22 & 44 & 66 & \multicolumn{2}{|c|}{36} \\
\hline
\end{tabular}

\begin{tabular}{|c|c|c|c|c|}
\hline $\begin{array}{l}\text { Design and } \\
\text { Sensors }\end{array}$ & 18 & 39 & 57 & $\%^{31}$ \\
\hline $\begin{array}{l}\text { Simulations } \\
\text { of UAS }\end{array}$ & 7 & 37 & 44 & \\
\hline $\begin{array}{l}\text { Educational } \\
\text { Aspects }\end{array}$ & 1 & 2 & 3 & $\%^{2}$ \\
\hline $\begin{array}{c}\text { New } \\
\text { Knowledge } \\
\text { base on UAS }\end{array}$ & 5 & 8 & 13 & $\%^{7}$ \\
\hline Total & 53 & 130 & 183 & $\begin{array}{l}10 \\
0 \%\end{array}$ \\
\hline
\end{tabular}

In the research perspective, there is the possibility of carrying out studies for a new application of UAS for cargo purpose, sensors integrations, simulation and introduce to the educational environment. Although, the findings show that UAS will be evaluating in the construction industry with the RBG camera sensors, for photogrammetry purpose. Then, new sensors will be incorporate generating novels applications and methods to execute UAS operations. Furthermore, software, drivers and platforms will be utilising UAS as a development foundation and finally, the educational aspect will be incorporated in the classrooms of the built environment and engineering careers. Depending on the publication number related to the literature found the evolution of the UAS on research field can be described in Figure 7.

\section{Fig 7; Evolution map of UAS in the construction}

\section{B. Construction Tasks}

The literature identifies the issue in the area of damage quantification, surveying, health and safety, cost-effective solution, visualization management, monitoring and progress, urban planning, Thermal Image, and traffic solution that with a proper strategy of UAS is able to address. The following table describes the construction stages of UAS implementation.

The tasks most written about presented in table VIII are concerning the damage quantification and Health \& Safety. This task of damage quantification is addressing the issues of unsafety areas or prevent future safety issues to town or cities such as Landslides or damage in infrastructure of bridges, dams and structural foundations. In addition, the tasks have been intensively improved since the UAS was implemented to address the issues found such as: image quality, faster data quantification, cost effective solution and achievable on time. Only the tasks related to health and safety, visualisation and surveying have been found useful and fully implemented in an entire project which mean that project managers, site engineer, architects and parties involved in the project are benefit from the UAS outcome. The tasks that would need further research are in the area of traffic solutions. 
Systematic Literature Research of the Current Implementation of Unmanned Aerial System (UAS) in the Construction Industry

Table- VIII: Description of tasks and Construction stages of UAS implementation

\begin{tabular}{|c|c|c|c|c|c|c|c|c|c|}
\hline No. & Tasks & Stage & $\begin{array}{c}\text { Entire } \\
\text { Implemented }\end{array}$ & Journal & Conference & Totals & $\%$ & Journal & Conference \\
\hline 1 & $\begin{array}{c}\text { Damage } \\
\text { Quantification }\end{array}$ & $\begin{array}{c}\text { Pre- } \\
\text { Construction } \\
\text { Construction, } \\
\text { Post } \\
\text { construction }\end{array}$ & & 7 & 8 & 15 & $22.7 \%$ & $\begin{array}{c}{[20][21]} \\
{[22][23]} \\
{[24][25]} \\
{[26]}\end{array}$ & $\begin{array}{c}{[27][28][29]} \\
{[30][31][32]} \\
{[33][34]}\end{array}$ \\
\hline 2 & $\begin{array}{l}\text { Health and } \\
\text { Safety }\end{array}$ & $\begin{array}{c}\text { Strategy, } \\
\text { Pre- } \\
\text { Construction } \\
\text { Construction, } \\
\text { Post } \\
\text { construction } \\
\end{array}$ & $\mathrm{X}$ & 2 & 8 & 10 & $15.2 \%$ & [35] [36] & $\begin{array}{c}{[37][38][39]} \\
{[40][41][42]} \\
{[43][44]}\end{array}$ \\
\hline 3 & Visualisation & $\begin{array}{c}\text { Strategy } \\
\text { Construction } \\
\text { Post } \\
\text { Construction } \\
\end{array}$ & & 5 & 4 & 9 & $13.6 \%$ & $\begin{array}{c}45][46] \\
{[47][48]} \\
{[49]}\end{array}$ & $\begin{array}{c}{[50][13][51]} \\
{[52]}\end{array}$ \\
\hline 4 & Surveying & $\begin{array}{c}\text { Strategy, } \\
\text { Pre- } \\
\text { Construction } \\
\text { Construction, } \\
\text { Post } \\
\text { construction }\end{array}$ & $X$ & 4 & 5 & 9 & $13.6 \%$ & $\begin{array}{c}{[3][53]} \\
{[54][55]}\end{array}$ & $\begin{array}{c}{[56][60][57]} \\
{[58][59]}\end{array}$ \\
\hline 5 & $\begin{array}{l}\text { Monitoring \& } \\
\text { Progress }\end{array}$ & $\begin{array}{c}\text { Strategy } \\
\text { Construction } \\
\text { Post } \\
\text { Construction } \\
\end{array}$ & & 1 & 8 & 9 & $13.6 \%$ & {$[60]$} & $\begin{array}{c}61][62][63] \\
{[64][65][66]} \\
{[67][68]}\end{array}$ \\
\hline 6 & $\begin{array}{c}\text { Administrative } \\
\text { Perspective }\end{array}$ & $\begin{array}{c}\text { Strategy } \\
\text { Construction }\end{array}$ & & 1 & 6 & 7 & $10.6 \%$ & [69] & $\begin{array}{l}{[70][71][72]} \\
{[73][74][75]} \\
\end{array}$ \\
\hline 7 & Urban Planning & $\begin{array}{c}\text { Strategy } \\
\text { Pre- } \\
\text { Construction } \\
\text { Construction } \\
\end{array}$ & & 1 & 2 & 3 & $4.7 \%$ & [76] & [77] [78] \\
\hline 8 & Thermal Images & $\begin{array}{l}\text { Construction } \\
\text { Post- } \\
\text { Construction }\end{array}$ & & 1 & 1 & 2 & $3 \%$ & [79] & [80] \\
\hline 9 & Traffic Solution & $\begin{array}{c}\text { Strategy } \\
\text { Pre- } \\
\text { Construction } \\
\end{array}$ & & 0 & 2 & 2 & $3 \%$ & & [81] [82] \\
\hline & Total & & & 22 & 44 & 66 & $100 \%$ & & \\
\hline
\end{tabular}

\section{Discussion}

Furthermore, the literature illustrates that UAS would be the next generation of monitoring construction performance in term of safety management. The researchers show the construction stage assessing an UAS operation on construction site produce significant increase in the rates of productivities which is described such as the data collection, data analysed by the sole images or the completing 3D model images contrasting them with the initial BIM models, monitoring safety, evaluation of the civil infrastructure conditions and fast communication of the project update onsite and off-site project. These benefits in communication can be mixed with lean construction principles and the last planner system to enhance the optimal potential of the images obtained.

During the stages, the UAS can be applied for the different specific task. However, the main driven to implement it is the need of delivering quality, faster, understandable and reliable information to the stakeholders in the projects. Otherwise, technology is being presented as an emerging technology which is opening new possibilities to address the need for quality and efficient work.
The future of this technology is making possible automation the construction industry to reduce fatalities, reworks and over costs and time dismissing as a consequence of human mistakes. Therefore, artificial intelligence and autonomous robots will be managing step by step while the industry is presenting progress on virtual reality basis. The aspect of UAS cargo is embedding the chance to create transport and designs automated process with the UAS. The digitalisation of the construction industry is flourishing and it is making more understandable the projects and satisfactory experience achieving client's expectation and creating sustainable cities across the world.

The educational sector will be reinforced addressing the needs of implementing new technology achieving higher level of quality in the construction site saving costs. The introduction of the UAS in the curricula is directed to surveying. However, progress report and BIM application are making possible the increment on the educational

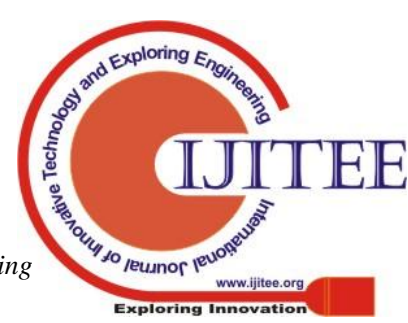


demand of the UAS studies.

\section{CONCLUSION}

The aim of this research was conduct in a systematic literature review regarding the actual implementation of UAS in the construction industry covering the most relevant tasks, cases, areas of usage and the reasons of applying it. In order to accomplish successfully the aim, a bibliographic peer-review database was composed by 1,397 journal and conference papers. The database reveals that UAS literature tempts to publish more in conferences than journals. The actual implementation is more accepted by journal publication considering the post-construction valuable than another implementation. Furthermore, the construction stage is the most investigated topic up today by researchers. The actual implementation of UAS has seen in countries such as the United States of America, Germany, China, Australia, and the United Kingdom as a result of their policy and market acceptance and regulation. Other countries such as Poland, Indonesia, Canada South Korean and Italy are in their first step and integration in their research field.

The database found was classified in five different aspects which are related to the actual implementation of UAS, designing and testing new sensors, UAS simulations, educational aspects and papers which mention UAS as a part of their intent to create new knowledge. As discussed, the literature about UAS evolution and growth is tending to be in five stages. The first stage is related to the visual and geometrical data collection sensors which are cameras and Lidar. Then, the second stage is showing the sensors that the UAS can cargo different the first stage such as decibels and gas measurement. Furthermore, the third stage is related to the programming part of the UAS. Divers simulation cases are managing in terms of feasibility of UAS missions. After that, software and platforms are available to complement the UAS outcomes as creating 3D models. Finally, all the system created and tested will be incorporated into schools and university with the aim to encourage the jobs of tomorrow.

In addition, the actual implementation of UAS most used is in the field of damage quantification. This application has reduced significantly time and cost of inspections and elevate the clients understanding in terms of visual idea exchange through the visualization management. Therefore, the implementation in health and safety have been relevant in the UAS applications in construction. The implementation in this field is regarding safety inspections, air pollution monitoring and decibels measurements. The next direct application in the administrative perspective is visualization management in order to enhance the communication level of the parties involved in the project. Implementations in the field of Urban planning are concerning city planning prevention. Moreover, the energy measurement is applied to identify façade thermal conditions.

In conclusion, the UAS technology is significantly changing methods of assessing current jobs in the construction industry. Otherwise, a fully autonomous flight of UAS is still an area for research along with the sensors of 360 camera RBG, artificial intelligence algorithm integration and UAS cargo in the construction industry.
Some of these researches might contribute to monitoring construction site, mitigate risk zones, improve the visualization management experience and still finding novel methods to make more efficient the construction industry. However, it seems that the technology is purely novel in the aspect of UAS integration and on the following years could be developed as the market might be demanding this type of solution. The UAS is a field of study that requires further research in the construction and other industries.

\section{ACKNOWLEDGMENT}

Acknowledgement to the Ministry of Higher Education Science and Technology of the Dominican Republic for sponsor the research.

\section{REFERENCES}

1. A. Haylen, "Civilian Drones," Feb 2019. [Online] Available:

https://www.google.com/url? sa $=\mathrm{t} \& \mathrm{rct}=\mathrm{j} \& \mathrm{q}=\& \mathrm{esrc}=\mathrm{s} \&$ so urce $=$ web $\&$ cd $=1 \&$ ved $=2$ ahUKEwjLpcmq 8 tzjAhV7QhUI HaBrDvoQFjAAegQIABAC\&url=http\%3A\%2F\%2Fres earchbriefings.files.parliament.uk\%2Fdocuments $\% 2 \mathrm{FCB}$ P-7734\%2FCBP-

7734.pdf\&usg=AOvVaw1H10WIN_CJ2afxfInEFnZx [Accessed 2019].

2. T. F. Sonnemann, J. U. Hung and C. L. Hofman, "Mapping Indigenous Settlement Topography in the Caribbean Using Drones," Remote Sensing, vol. 8, no. 10, p. 791, Sept 2016.

3. T. J. Siebert S., "Mobile 3D mapping for surveying earthwork projects using an Unmanned Aerial Vehicle (UAV) system," Automation in Construction, vol. 41, pp. 1-14, 2014.

4. A. Pérez-Alberti and A. S. Trenhaile, "An initial evaluation of drone-based monitoring of boulder beaches in Galicia, north-western Spain," EARTH SURFACE PROCESSES AND LANDFORMS, 2014.

5. R. R. S. d. Melo, D. B. Costa, J. S. Álvarez and J. Irizarry, "Applicability of unmanned aerial system (UAS) for safety inspection on construction sites," Safety Science, vol. 98, pp. 174-185, 2017.

6. W.W.Immerzeel, P.D.A.Kraaijenbrink, J.M.Sheab, A.B.Shrestha, F.Pellicciotti, M.F.P.Bierkens and S. Jonga, "High-resolution monitoring of Himalayan glacier dynamics using unmanned aerial vehicles," Remote Sensing of Environment, vol. 150, pp. 93-103, July 2014.

7. C.I.O.B, "Content," in Code of Practice for Project Management for Construction and Development, Oxford, The Chaptered Institute of Building, 2014, pp. 10-40.

8. M. C. Tatum and J. Liu, "Unmanned Aircraft System Applications in Construction," Procedia Engineering, vol. 196, pp. 167-175, 2017

9. ICAO, "icao.int," 2011. [Online]. Available: https://www.icao.int/meetings/uas/documents/circular\%2 0328_en.pdf. [Accessed 705 2017].

10. J. S. Álvares, D. B. Costa and R. R. S. d. Melo, "Exploratory study of using unmanned aerial system imagery for construction site 3D mapping," Construction Innovation, vol. 18, no. 3, pp. 301-320, 2018.

11. S. Zhou and M. Gheisari, "Unmanned aerial system applications in construction: a systematic review," Construction Innovation, pp. 453-468, 2018.

12. R. R. S. d. Melo, D. B. Costa, J. S. Álvares and J. 
Irizarry, "Applicability of unmanned aerial system (UAS) for safety inspection on construction sites," Safety Science, vol. 98, no. https://doi.org/10.1016/j.ssci.2017.06.008, pp. 174-185, 2017.

13. W.W.Immerzeel, P.D.A.Kraaijenbrink, J.M.Shea, A.B.Shrestha, F.Pellicciotti, M.F.P.Bierkens and S. Jong, "High-resolution monitoring of Himalayan glacier dynamics using unmanned aerial vehicles," Remote Sensing of Environment, vol. 150, pp. 93-103, 2014.

14. Q. Chen, B. G. d. Soto and B. T.Adey, "Construction automation: Research areas, industry concerns and suggestions for advancement," Automation in Construction, vol. 94, pp. 22-38, 2018.

15. S. Tuttas, A. Braun, A. Borrmann and U. Stilla, Construction Site Monitoring," in ISPRS - International Archives of the Photogrammetry, Remote Sensing and Spatial Information Sciences, Munich, 2016.

16. FAA, "Unmanned Aircraft Systems (UAS)," 04052019. [Online]. Available: https://www.faa.gov/uas/. [Accessed 0405 2019].

17. B. Lillian, "unmanned-aerial.com," 2510 2017. [Online]. Available: https://unmanned-aerial.com/dot-launch-uasintegration-pilot-program-public-private-sectorcollaboration. [Accessed 2019].

18. G. Morgenthal, N. Hallermann, J. Kersten, J. Taraben, P. Debus, M. Helmrich and V. Rodehorst, "Framework for Automated UAS-based structure condition assessment of 2019.

19. CAA, "caa.co.uk," 0405 2019. [Online]. Available: https://www.caa.co.uk/Commercialindustry/Aircraft/Unmanned-aircraft/Smalldrones/Regulations-relating-to-the-commercial-use-ofsmall-drones/. [Accessed 2019].

20. Q. Quan, "Introduction," in Introduction to Multicopter Design and Control, Beijing, Springer, 2017.

21. CASA, "Civil Aviation Safety Authority," 15042019. [Online]. Available: https://www.casa.gov.au/aircraft/landing-page/flyingdrones-australia. [Accessed 0505 2019].

22. A. Trounson, "pursuit.unimelb.edu.au," 21112017. [Online]. Available: https://pursuit.unimelb.edu.au/articles/editing-farmingthe-future. [Accessed 0505 2019].

23. K. A. T. A. P. D. Kijewski-Correa T.L., "Field reconnaissance and overview of the impact of Hurricane Matthew on Haiti's Tiburon Peninsula," Natural Hazards, vol. 94, no. 2, pp. 627-653, 2018. Y., "Mechanism of the December 2015 Catastrophic Landslide at the Shenzhen Landfill and Controlling Geotechnical Risks of Urbanization," Engineering, vol. 2, no. 2, pp. 230-249, 2016.

25. L. J. Z. D. Greenwood W.W., "Applications of UAVs in civil infrastructure," Journal of Infrastructure Systems, vol. 25 , no. 2, 2019.

26. Q. Zhan, F. Zou, W. Zhang and Y. Xiao, "Research and Practice on Disaster Prevention Planning in Villages based on Planning Support System: Overview: Potential public policies on spatial planning for sustainable urban forms A Case Study," International review for spatial planning and sustainable development A: Planning Strategies and Design Concepts, vol. 6, no. 4, pp. 110127, 2018.

27. W. T. Eschmann C., "Web-based georeferenced 3D inspection and monitoring of bridges with unmanned aircraft systems," Journal of Surveying Engineering, vol. 143, no. 3, 2017. "Evaluation of Acquisition Strategies for Image-Based bridges," Automation in Construction, vol. 97, pp. 77-95,

24. L. B. W. W. Z. L. X. Q. G. Y. Z. N. C. H. L. T. L. A. Yin

28. W. C. Schach R., "Construction inspection with unmanned aerial vehicle [Bauwerksinspektion mit unbemannten Flugsystemen]," Bauingenieur, vol. 92, no. June, pp. 271-279, 2017.

29. D. R. W. H. Y. G.-T. L. W. Liu C.-A., "A 3D laboratory test-platform for overhead power line inspection," International Journal of Advanced Robotic Systems, vol. 13, no. 2, 2016

30. G. M. C. G. C. N. B. A. U. F. Pepi C., "Dynamic characterization of a severely damaged historic masonry bridge," in Procedia Engineering, Perugia, 2017.

31. Shabah A, "HUMANIT3D for Disaster Response: An Assessment of Mass Customization on Organizational Performance under Turbulent Environments," in Procedia Engineering, Montreal, 2015.

32. O. M. V. G. Martellone A., "Knowledge, conservation and technologies: A research project on the streets of Ancient Pompeii," Pompei, 2018.

33. S. A. Kucuksubasi F., "Transfer learning-based crack detection by autonomous UAVs," Sorguc, 2018.

34. P. C. Pereira F.C., "Embedded image processing systems for automatic recognition of cracks using UAVs," in IFAC-PapersOnLine, 2015.

35. S. S. C. S. Kim H., "Unmanned aerial vehicle (UAV)powered concrete crack detection based on digital image processing," in International Conference on Advances in Experimental Structural Engineering, Ulsan, 2015.

36. Z. X. S. M. Z. Q. Pan Y., "Object-based and supervised detection of potholes and cracks from the pavement images acquired by UAV," 2017.

37. G. V. B. G. Barrile V., "UAV and computer vision in 3D modeling of cultural heritage in southern Italy," in IOP Conference Series: Materials Science and Engineering, 2017.

38. Z. N. N. E. C. C. Alvear O., "Using UAV-based systems to monitor air pollution in areas with poor accessibility," Journal of Advanced Transportation, vol. 2017, 2017.

39. A. A. F. J. Namian M., "Effect of Distraction on Hazard Recognition and Safety Risk Perception," Journal of Construction Engineering and Management, vol. 32, no. $5,2018$.

40. D. M. R. Á. J. B. A. Costa D.B., "Evaluating the performance of unmanned aerial vehicles for safety inspection," 2016.

41. B. G. Baker W.L., "A theoretical construct for progressive construction site safety implementing situational awareness in unmanned aircraft systems to improve decision-making and safety," 2017.

42. E. B. Gheisari M., "Unmanned Aerial Systems (UAS) for Construction Safety Applications," in Construction Research Congress 2016: Old and New Construction Technologies Converge in Historic San Juan Proceedings of the 2016 Construction Research Congress, CRC 2016, Gainesville, 2016.

43. I. J. C. D. Kim S., "Potential Factors Influencing the Performance of Unmanned Aerial System (UAS) Integrated Safety Control for Construction Worksites," in Construction Research Congress 2016: Old and New Construction Technologies Converge in Historic San Juan - Proceedings of the 2016 Construction Research Congress, CRC 2016, Atlanta, 2016.

44. L. T. Li R.Y.M., "Leading safety indicators and automated tools in the construction industry," in ISARC 2017 - Proceedings of the 34th International Symposium on Automation and Robotics in Construction, Hong Kong, 2017.

45. T. T. S. S. A. H. K. S. O. Y. Tomita H., "Development of

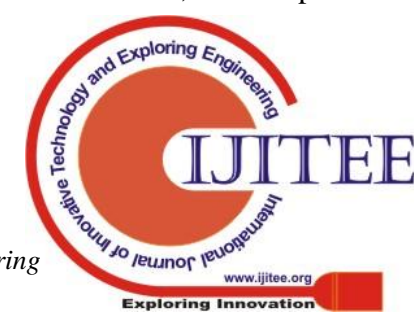


UAV indoor flight technology for building equipment works," Shinryo, 2017.

46. Z. N. N. E. C. C. Alvear O.A., "A chemotactic pollutionhoming UAV guidance system," in 2017 13th International Wireless Communications and Mobile Computing Conference, IWCMC 2017, Valencia, 2017.

47. Takaku T, "Workability and mobility of construction machinery: Systematic approach to engineering matters," Kanagawa, 2015.

48. C. S. B. T. C. S. Puppala A.J., "Visualization of civil infrastructure emphasizing geomaterial characterization and performance," Journal of Materials in Civil Engineering, vol. 30, no. 10, 2018.

49. M. B. D. S. Hamledari H., "Automated computer visionbased detection of components of under-construction indoor partitions," Automation in Construction, vol. 74, pp. 78-94, 2017.

50. R. B. Wischounig-Strucl D., "Resource aware and incremental mosaics of wide areas from small-scale UAVs," Machine Vision and Applications, vol. 26, pp. 885-994, 2015.

51. Tezel A and A. Z, "From conventional to it based visual management: A conceptual discussion for lean construction," Journal of Information Technology in Construction, vol. 22, pp. 220-246, 2017.

52. H. Q. P. K. Camargo A., "Performance evaluations for super-resolution mosaicing on UAS surveillance videos," International Journal of Advanced Robotic Systems, vol. 10, 2013.

53. D. G. P. M. V. A. D. W. A. Stal C., "Towards Costefficient prospection and 3D visialization of underwater structures using compact ROVs," 2015.

54. H. Y. Kamari M., "Automated filtering big visual data from drones for enhanced visual analytics in construction," in ISARC 2017 - Proceedings of the 34th International Symposium on Automation and Robotics in Construction, Hong Kong, 2017.

55. L. Ferguson and L. Waugh, "Augmented and virtual reality in combination with unmanned aerial vehicles: A literature review," in Canadian Society for Civil Engineering Annual Conference 2015: Building on Our Growth , Regina, 2015

56. M. E. S. T. Bhatawdekar R.M., "Selection of lidar technology for limestone quarry in Thailand," Journal of Mines, Metals and Fuels, vol. 65, no. 7, pp. 393-399, 2017.

57. M. W. Z. Z. Z. Y. Y. J. C. X. L. S. Y. S. Luo L., "Integration of terrestrial laser scanning and soil sensors for deformation and hydrothermal monitoring of frost mounds," Measurement: Journal of the International Measurement Confederation, vol. 131, pp. 513-523, 2019.

58. M. Pepe, "Image-based methods for metric surveys of buildings using modern optical sensors and tools: From 2D approach to 3D and vice versa," International Journal of Civil Engineering and Technology, vol. 9, no. 9, pp. 729-745, 2018.

59. D. J.-P. S. M. A. D. Mongrédien C., "Centimeter-level positioning for UAVs and other mass-market applications," Findland, 2016.

60. S. Siebert and J. Teizer, "Mobile 3D mapping for surveying earthwork using an unmanned aerial vehicle (UAV)," in ISARC 2013 - 30th International Symposium on Automation and Robotics in Construction and Mining, Held in Conjunction with the 23rd World Mining Congress, Montreal, 2013.

61. G. M. Hopes, "Former Mercury Mining Activity Remediation-Repository Construction and Site Reclamation in the California Coast Range," Sacramento, California, 2017.
62. S. H. O. K. H. K. K. M. Nakano K., "On a fundamental evaluation of a UAV equipped with a multichannel laser scanner," in International Archives of the Photogrammetry, Remote Sensing and Spatial Information Sciences - ISPRS Archives, Saitama, 2018.

63. D. Avola, G. L. Foresti, N. Martinel, C. Micheloni, D. Pannone and C. Piciarelli, "Real-Time Incremental and Geo-Referenced Mosaicking by Small-Scale UAVs," in Image Analysis and Processing - ICIAP 2017, 2017.

64. B. I. Vick S., "Road Design Layer Detection in Point Cloud Data for Construction Progress Monitoring," Journal of Computing in Civil Engineering, vol. 32, no. 5, 2018.

65. H. A. M. B. S. A. Nahangi M., "Automated localization of UAVs in GPS-denied indoor construction environments using fiducial markers," Toronto, 2018.

66. A. Zingoni, M. Diani, G. Corsini and A. Masini, "REALTIME 3D RECONSTRUCTION FROM IMAGES TAKEN FROM AN UAV," in The International Archives of the Photogrammetry, Remote Sensing and Spatial Information Sciences, La Grande Motte, 2015.

67. Malara J, "The use of modern technologies in conducting research on the performance of construction workers," in AIP Conference Proceedings, Kraków, 2018.

68. Z. Shang and Z. Shen, "Real-Time 3D Reconstruction on Construction Site Using Visual SLAM and UAV," in Construction Research Congress 2018, New Orleans, 2018.

69. K. S. C. S. L. S. K. T. Moon D.Y., "Pre-processing methodology of image compensation using histogram equalization for generating point-cloud of construction environment," SungKyunKwan, 2017.

70. D. A. W. A. K. M. Skorupka D., "Optimization of the choice of unmanned aerial vehicles used to monitor the implementation of selected construction projects," AIP Conference Proceedings, vol. 1863, 2017.

71. C. C. B. A. M. J. Bognot J.R., "BUILDING CONSTRUCTION PROGRESS MONITORING USING UNMANNED AERIAL SYSTEM (UAS), LOW-COST PHOTOGRAMMETRY, and GEOGRAPHIC INFORMATION SYSTEM (GIS)," in ISPRS Annals of the Photogrammetry, Remote Sensing and Spatial Information Sciences, Quezon City, 2018.

72. S. C. G. D. C. T. O. M. Javadnejad F., "An Assessment of UAS-Based Photogrammetry for Civil Integrated Management (CIM) Modeling of Pipes," Corvallis, 2017.

73. V. R. P. Kumar, M. Balasubramanian and S. J. Raj, "Robotics in Construction Industry," Indian Journal of Science and Technology, vol. 9, no. 23, 2016.

74. I. R. Blinn N., "Feasibility Assessment of Unmanned Aircraft Systems for Construction Management Applications," Gainesville, 2016.

75. Kim and Irizarry, "Framework for human performance analysis in Unmanned Aircraft System (UAS) operations in dynamic construction environment," 2018.

76. S.-V. J. R. U. B. E. R. D. Bručas D., "Implementation and testing of low cost UAV platform for orthophoto imaging," 2013.

77. S. A. G. K. W. J.-H. Fassbender J., "Improved productivity, efficiency and cost savings following implementation of drone technology in the surveying industry," in ISARC 2018 - 35th International Symposium on Automation and Robotics in Construction and International AEC/FM Hackathon: The Future of Building Things, Milwaukee, 2018.

78. K. R. Amanu D.K., "Right of way surveillance, maintenance, and higher production opportunities on 
Systematic Literature Research of the Current Implementation of Unmanned Aerial System (UAS) in the Construction Industry

Banyu Urip Export Pipeline," 2017.

79. ZhuB, "The application of the unmanned aerial vehicle remote sensing technology in the FAST project construction," in Proceedings of SPIE - The International Society for Optical Engineering, 2015.

80. X. J. Z. J. Adler B., "Autonomous Exploration of Urban Environments using Unmanned Aerial Vehicles," Journal of Field Robotics, vol. 31, no. 6, pp. 912-939, 2014.

81. W. L. N. Z. T. M. Yu B., "Unsupervised building extraction using remote sensing data to detect changes in land use," in Proceedings of SPIE - The International Society for Optical Engineering, Beijing, 2014.

82. VargheseA, G. J, R. A and B. P, "ChangeNet: A deep learning architecture for visual change detection," Bengaluru, 2018.

83. B. L. B. R. R. F. Previtali M., "Thermographic analysis from uav platforms for energy efficiency retrofit applications," Journal of Mobile Multimedia, vol. 9, no. 2, pp. 66-82, 2013.

84. K. Y. Rotkevich A.S., "Method of study mechanical and thermal processes of receiver-computer unit for unmanned aerial vehicles," Kofanov, 2016.

85. C. C. G. M. I. J. J. E. Karan E.P., "A comprehensive matrix of unmanned aerial systems requirements for potential applications within a department of transportation," 2014.

86. K. J. Č. P. P. J. Šafár V., "Comparison of methods to map selected traffic markings on first class roads in the Czech Republic," Praha, 2018.

\section{APPENDIX}

List of Journals chosen by Date

\begin{tabular}{|c|c|c|}
\hline Fig. 1. No. & Fig. 2. $\quad$ Year & Fig. 3. Journal \\
\hline Fig. 4. 1 & Fig. 5. 2019 & $\begin{array}{l}\text { Fig. 6. Measurement: } \\
\text { Journal of the International } \\
\text { Measurement } \\
\text { Confederation }\end{array}$ \\
\hline Fig. $7 . \quad 2$ & Fig. 8. 2019 & $\begin{array}{l}\text { Fig. } 9 . \quad \text { Journal of } \\
\text { Infrastructure Systems }\end{array}$ \\
\hline Fig. 10. 3 & Fig. 11. 2019 & $\begin{array}{l}\text { Fig. 12. Journal of } \\
\text { Instrumentation }\end{array}$ \\
\hline Fig. 13. 4 & Fig. 14. 2018 & $\begin{array}{l}\text { Fig. 15. International } \\
\text { Journal of Civil } \\
\text { Engineering and } \\
\text { Technology } \\
\end{array}$ \\
\hline Fig. 16. 5 & Fig. 17. 2018 & $\begin{array}{l}\text { Fig. 18. Journal of } \\
\text { Construction Engineering } \\
\text { and Management }\end{array}$ \\
\hline Fig. 19. 6 & Fig. 20. 2018 & Fig. 21. Natural Hazards \\
\hline Fig. 22. 7 & Fig. 23. 2018 & $\begin{array}{l}\text { Fig. 24. Journal of } \\
\text { Computing in Civil } \\
\text { Engineering }\end{array}$ \\
\hline Fig. 25. 8 & Fig. 26. 2018 & $\begin{array}{l}\text { Fig. 27. Journal of } \\
\text { Materials in Civil } \\
\text { Engineering }\end{array}$ \\
\hline Fig. 28. 9 & Fig. 29. 2018 & Fig. 30. Buildings \\
\hline Fig. 31. 10 & Fig. 32. 2018 & $\begin{array}{l}\text { Fig. 33. International } \\
\text { Review for Spatial } \\
\text { Planning and Sustainable } \\
\text { Development }\end{array}$ \\
\hline Fig. 34. 11 & Fig. 35. 2017-2014 & $\begin{array}{l}\text { Fig. 36. Automation in } \\
\text { Construction }\end{array}$ \\
\hline Fig. 37. 12 & Fig. 38. 2017 & $\begin{array}{l}\text { Fig. 39. Journal of } \\
\text { Advanced Transportation }\end{array}$ \\
\hline Fig. 40.13 & Fig. 41. 2017 & $\begin{array}{l}\text { Fig. 42. Journal of } \\
\text { Information Technology in } \\
\text { Construction }\end{array}$ \\
\hline Fig. 43. 14 & Fig. 44. 2017 & $\begin{array}{l}\text { Fig. 45. Journal of } \\
\text { Advanced Transportation }\end{array}$ \\
\hline Fig. 46. 15 & Fig. 47. 2017 & Fig. 48. Journal of \\
\hline
\end{tabular}

\begin{tabular}{|l|l|l|}
\hline & & Surveying Engineering \\
\hline Fig. 49. 16 & Fig. 50. 2017 & Fig. 51. Bauingenieur \\
\hline Fig. 52.17 & Fig. 53. 2017 & $\begin{array}{l}\text { Fig. 54. Journal of } \\
\text { Mines, Metals and Fuels }\end{array}$ \\
\hline Fig. 55. 18 & Fig. 56. 2016-2013 & $\begin{array}{l}\text { Fig. 57. International } \\
\text { Journal of Advanced } \\
\text { Robotic Systems }\end{array}$ \\
\hline Fig. 58. 19 & Fig. 59. 2016 & Fig. 60. Engineering \\
\hline Fig. 61. 20 & Fig. 62. 2016 & $\begin{array}{l}\text { Fig. 63. Indian Journal } \\
\text { of Science and Technology }\end{array}$ \\
\hline Fig. 64. 21 & Fig. 65. 2015 & $\begin{array}{l}\text { Fig. 66. Machine Vision } \\
\text { and Applications }\end{array}$ \\
\hline Fig. 67. 22 & Fig. 68. 2014 & $\begin{array}{l}\text { Fig. 69. Automation in } \\
\text { Construction }\end{array}$ \\
\hline Fig. 70. 23 & Fig. 71. 2014 & $\begin{array}{l}\text { Fig. 72. Journal of Field } \\
\text { Robotics }\end{array}$ \\
\hline Fig. 73. 24 & Fig. 74. 2013 & $\begin{array}{l}\text { Fig. 75. International } \\
\text { Journal of Advanced } \\
\text { Robotic Systems }\end{array}$ \\
\hline Fig. 76. 25 & Fig. 77. 2013 & $\begin{array}{l}\text { Fig. 78. Journal of } \\
\text { Mobile Multimedia }\end{array}$ \\
\hline
\end{tabular}

List of Conferences chosen by Date

\begin{tabular}{|l|l|l|l}
\hline Fig. 79. $\mathrm{N}$ & Fig. 80. Ye & Fig. 81. Conferen & Fig. 82. Amo
\end{tabular}

\begin{tabular}{|l|l|l|l|}
\hline $\begin{array}{l}\text { Fig. 79. N } \\
\text { o. }\end{array}$ & $\begin{array}{l}\text { Fig. 80. Ye } \\
\text { ars }\end{array}$ & $\begin{array}{l}\text { Fig. 81. Conferen } \\
\text { ces }\end{array}$ & $\begin{array}{l}\text { Fig. 82. Amo } \\
\text { unt }\end{array}$ \\
\hline Fig. 83. 1 & $\begin{array}{l}\text { Fig. 84. 20 } \\
19\end{array}$ & $\begin{array}{l}\text { Fig. 85. Lecture } \\
\text { Notes in Computer } \\
\text { Science (including } \\
\text { subseries Lecture } \\
\text { Notes in Artificial } \\
\text { Intelligence and } \\
\text { Lecture Notes in } \\
\text { Bioinformatics) }\end{array}$ & Fig. 86. 1 \\
\hline Fig. 87. 2 & $\begin{array}{l}\text { Fig. 88. 20 } \\
18-2017\end{array}$ & $\begin{array}{l}\text { Fig. 89. AIP } \\
\text { Conference } \\
\text { Proceedings }\end{array}$ & Fig. 90. 2 \\
\hline Fig. 91. 3 & $\begin{array}{l}\text { Fig. 92. 20 } \\
18-2017\end{array}$ & $\begin{array}{l}\text { Fig. 93. IOP } \\
\text { Conference Series: } \\
\text { Materials Science } \\
\text { and Engineering }\end{array}$ & Fig. 94. 2 \\
\hline Fig. 95. 4 & $\begin{array}{l}\text { Fig. 96. 20 } \\
18-2017\end{array}$ & $\begin{array}{l}\text { Fig. 97. ISPRS } \\
\text { Annals of the } \\
\text { Photogrammetry, } \\
\text { Remote Sensing and } \\
\text { Spatial Information } \\
\text { Sciences }\end{array}$ & Fig. 98. 2 \\
\hline Fig. 103.6 99. 5 & $\begin{array}{l}\text { Fig. 100.20 } \\
18-2013\end{array}$ & $\begin{array}{l}\text { Fig. 101.Internatio } \\
\text { nal Archives of the } \\
\text { Photogrammetry, } \\
\text { Remote Sensing and } \\
\text { Spatial Information } \\
\text { Sciences - ISPRS } \\
\text { Archives }\end{array}$ & Fig. 102.4 \\
\hline Fig. 107.7 & $\begin{array}{l}\text { Fig. 105.Construct } \\
\text { ion Research } \\
\text { Congress 2014: } \\
\text { Construction in a } \\
\text { Global Network - } \\
\text { Proceedings of the } \\
\text { 2014 Construction } \\
\text { Research Congress }\end{array}$ & Fig. 106.5 \\
\hline 18 108.20 & $\begin{array}{l}\text { Fig. 109.Chinese } \\
\text { Control Conference, } \\
\text { CCC }\end{array}$ & Fig. 110.1 \\
\hline
\end{tabular}




\begin{tabular}{|c|c|c|c|}
\hline Fig. 111.8 & $\begin{array}{l}\text { Fig. 112.20 } \\
\text { 18-2013 }\end{array}$ & $\begin{array}{l}\text { Fig. 113.ISARC } \\
2013 \text { - 30th } \\
\text { International } \\
\text { Symposium on } \\
\text { Automation and } \\
\text { Robotics in } \\
\text { Construction and } \\
\text { Mining, Held in } \\
\text { Conjunction with } \\
\text { the 23rd World } \\
\text { Mining Congress }\end{array}$ & Fig. 114.9 \\
\hline Fig. 115.9 & $\begin{array}{l}\text { Fig. 116.20 } \\
17-2015\end{array}$ & $\begin{array}{l}\text { Fig. 117.Procedia } \\
\text { Engineering }\end{array}$ & Fig. 118.2 \\
\hline $\begin{array}{l}\text { Fig. } 119.1 \\
0\end{array}$ & $\begin{array}{l}\text { Fig. } 120.20 \\
17\end{array}$ & $\begin{array}{l}\text { Fig. 121.2017 } \\
\text { 13th International } \\
\text { Wireless } \\
\text { Communications } \\
\text { and Mobile } \\
\text { Computing } \\
\text { Conference, } \\
\text { IWCMC 2017 }\end{array}$ & Fig. 122.1 \\
\hline $\begin{array}{l}\text { Fig. } 123.1 \\
1\end{array}$ & $\begin{array}{l}\text { Fig. } 124.20 \\
17\end{array}$ & $\begin{array}{l}\text { Fig. 125.AUVSI } \\
\text { XPONENTIAL } \\
2017 \\
\end{array}$ & Fig. 126.1 \\
\hline $\begin{array}{l}\text { Fig. } 127.1 \\
2\end{array}$ & $\begin{array}{l}\text { Fig. } 128.20 \\
17\end{array}$ & $\begin{array}{l}\text { Fig. 129.Pipelines } \\
\text { 2017: Condition } \\
\text { Assessment, } \\
\text { Surveying, and } \\
\text { Geomatics - } \\
\text { Proceedings of } \\
\text { Sessions of the } \\
\text { Pipelines } 2017 \\
\text { Conference }\end{array}$ & Fig. 130.1 \\
\hline $\begin{array}{l}\text { Fig. } 131.1 \\
3\end{array}$ & $\begin{array}{l}\text { Fig. } 132.20 \\
17\end{array}$ & $\begin{array}{l}\text { Fig. 133. Society } \\
\text { of Petroleum } \\
\text { Engineers - } \\
\text { SPE/IATMI Asia } \\
\text { Pacific Oil and Gas } \\
\text { Conference and } \\
\text { Exhibition } 2017 \\
\end{array}$ & Fig. 134.1 \\
\hline $\begin{array}{l}\text { Fig. } 135.1 \\
4\end{array}$ & $\begin{array}{l}\text { Fig. } 136.20 \\
16\end{array}$ & $\begin{array}{l}\text { Fig. 137.2016 } \\
\text { IEEE Conference on } \\
\text { Quality } \\
\text { Management, } \\
\text { Transport and } \\
\text { Information } \\
\text { Security, } \\
\text { Information } \\
\text { Technologies, IT } \\
\text { and MQ and IS } 2016 \\
\end{array}$ & Fig. 138.1 \\
\hline $\begin{array}{l}\text { Fig. } 139.1 \\
5\end{array}$ & $\begin{array}{l}\text { Fig. } 140.20 \\
16\end{array}$ & $\begin{array}{l}\text { Fig. 141.29th } \\
\text { International } \\
\text { Technical Meeting } \\
\text { of the Satellite } \\
\text { Division of the } \\
\text { Institute of } \\
\text { Navigation, ION } \\
\text { GNSS 2016 } \\
\end{array}$ & Fig. 142.1 \\
\hline $\begin{array}{l}\text { Fig. } 143.1 \\
6\end{array}$ & $\begin{array}{l}\text { Fig. } 144.20 \\
16\end{array}$ & $\begin{array}{l}\text { Fig. 145.ACM } \\
\text { International } \\
\text { Conference } \\
\text { Proceeding Series } \\
\end{array}$ & Fig. 146.1 \\
\hline $\begin{array}{l}\text { Fig. } 147.1 \\
7\end{array}$ & $\begin{array}{l}\text { Fig. } 148.20 \\
16\end{array}$ & $\begin{array}{l}\text { Fig. 149.IGLC } \\
\text { 2016 - 24th Annual } \\
\text { Conference of the } \\
\text { International Group } \\
\text { for Lean } \\
\text { Construction }\end{array}$ & Fig. 150.1 \\
\hline $\begin{array}{l}\text { Fig. } 151.1 \\
8\end{array}$ & $\begin{array}{l}\text { Fig. 152.20 } \\
\text { 15-2014 }\end{array}$ & $\begin{array}{l}\text { Fig. 153.Proceedi } \\
\text { ngs of SPIE - The } \\
\text { International Society } \\
\text { for Optical } \\
\text { Engineering }\end{array}$ & Fig. 154.2 \\
\hline $\begin{array}{l}\text { Fig. } 155.1 \\
9\end{array}$ & $\begin{array}{l}\text { Fig. } 156.20 \\
15\end{array}$ & $\begin{array}{l}\text { Fig. 157.IFAC- } \\
\text { PapersOnLine }\end{array}$ & Fig. 158.1 \\
\hline Fig. 159.2 & Fig. 160.20 & Fig. 161.Proceedi & Fig. 162.1 \\
\hline
\end{tabular}

\begin{tabular}{|l|l|l|l|}
\hline 0 & 15 & $\begin{array}{l}\text { ngs of the 59th } \\
\text { Annual Meeting of } \\
\text { the International } \\
\text { Society for the } \\
\text { Systems Sciences }\end{array}$ & \\
\hline $\begin{array}{l}\text { Fig. 163.2 } \\
1\end{array}$ & $\begin{array}{l}\text { Fig. 164.20 } \\
15\end{array}$ & $\begin{array}{l}\text { Fig. 165.Proceedi } \\
\text { ngs, Annual } \\
\text { Conference - } \\
\text { Canadian Society } \\
\text { for Civil } \\
\text { Engineering }\end{array}$ & Fig. 166.1 \\
\hline
\end{tabular}

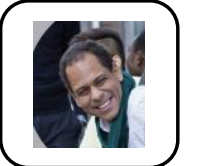

\section{AUTHORS PROFILE}

Hamlet Reynoso-Vanderhorst. is a $\mathrm{PhD}$ researcher at the Faculty of Science and Engineering, the University of Wolverhampton, researching the strategy of Unmanned Aerial System adoption process in the construction industry. He received a BEng in Civil Engineering from the Technology Institute of Santo Domingo (INTEC) the Dominican Republic and MSc in Construction Project Management from the University of Wolverhampton.

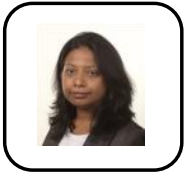

Dr Subashini Suresh has over 19 years of experience in research, teaching and practice in the area of Project Management and has worked in the area of Architecture, Engineering and Construction (AEC) sector in UK, USA, UAE, Nigeria, Ghana, Italy, Netherlands and India. Currently, she is a Reader of Construction Project Management at the School of Architecture and Built Environment, University of Wolverhampton. She holds a PhD in knowledge management. She received Rewarding Excellence Award for Innovation in Teaching and also for Blended Learning Tutor. She has published over 150 academic publications, which include 27 journal papers, 95 conference papers, four articles, eight book chapters, 15 reports and three books. Her key areas of interest are as follows: construction project management, knowledge management, building information modelling, health and safety, sustainability/green construction, emerging technologies, quality management, leadership in change management initiatives, organisational competitiveness, business process improvement, lean construction, risk management, and Six Sigma leadership.

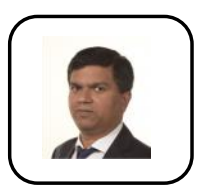

Dr suresh renukappa currently serves as a senior lecturer in the faculty of science and engineering at the university of wolverhampton. He holds a phd in managing change and knowledge associated with sustainability initiatives for improved competitiveness. $\mathrm{He}$ has over 20 years of research, consultancy, project management and teaching experience in a wide range of business and management areas across industrial sectors in both developed and emerging economies. His research interests cover, but not limited to, sustainability strategies for competitive advantage; carbon reduction strategies; corporate social responsibility; smart cities development; leading change towards sustainability; knowledge management; public private partnerships; cloud computing; infrastructure asset management; and sustainable infrastructure investment and development. He has successfully executed more than 30 large projects and authored over 100 papers which have been published in journals, book chapters and conference proceedings. 